\title{
Interactional Metadiscourse in English and Persian News Articles about 9/11
}

\author{
Sara Yazdani \\ Department of Linguistics, Ferdowsi University of Mashhad, Mashhad, Iran
}

Shahla Sharifi

Department of Linguistics, Faculty of Literature and Humanities, Ferdowsi University of Mashhad, Mashhad, Iran

\author{
Mahmoud Elyassi \\ Department of Linguistics, Faculty of Literature and Humanities, Ferdowsi University of Mashhad, Mashhad, Iran
}

\begin{abstract}
This study aimed to illuminate the role of interactional metadiscourse markers in English and Persian news articles about 9/11 events. For this purpose, 30 English and Persian news reports (15 from each) were collected randomly. In order to explore the frequency of these types of metadiscourse and their supposedly significant difference $s$ in both sets of data, Hyland classification system was utilized. The findings from the research illustrated a significant difference in distribution of metadiscourse markers in the corpus due to the fact that American journalist employed interactional metadiscourse markers more frequently in their news articles. Moreover, Iranian journalists inclined not use self-mention and engagement markers due to their reader responsibility and their writing styles in formal contexts. The results of the present study might offer insights to pedagogical implication of this aspect of metadiscourse for journalism students.
\end{abstract}

Index Terms - pragmatics, interactional metadiscourse, Hyland, 9/11 news articles, English \& Persian

\section{INTRODUCTION}

Pragmatics as a branch of linguistics deals with intended speaker meaning. David Crystal (Crystal, 1987, p.120) believed that "pragmatics studies the factors that govern our choice of language in social interaction and the effects of our choice on others." Regarding the cultural and contextual features in communication, it should be borne in mind that meaning could be more than just a simple interpretation of semantic or syntactic basis. Since 1970, researchers have become interested in investigating the meaning beyond the text in which they are occurring. Many researchers like Sassour, Moris, Carnap, Austin and Grice proposed useful theories that are still the basis of language researchers in this field. Finch (2000) claimed that "Pragmatists focus on what is not explicitly stated and on how we interpret utterances in situational contexts. They are concerned not so much with the sense of what is said as with its force, that is, with what is communicated by the manner and style of an utterance." Therefore, the importance of examining the meaning in relation to its context made researchers to think of linguistic means that represent it.

One of these means is metadiscourse. Hyland (2005) defines this concept as "an umbrella cover which is used for self-reflective statements to exchange the meaning through text, help the writer to mention his/her inputs and stances and engage reader as a member of specific community" (p.46). He believes that metadiscourse markers are not only more than a simple information exchange, but also might include writer's attitude, personality and regarding reader's assumption as well. Hyland claimed that "all metadiscourses are interpersonal for indicating reader's knowledge, textual experiences, and processing needs; and help writers with rhetorical appeals to achieve that."(Hyland, 2005, p.41)

Mass media are recognized as a means of discourse exchange and communication. Therefore, it would be helpful to examine the role of metadiscourse in relation between writer, text and reader as a contributing factor. Thus, the focus of this study is on metadiscourse use in English and Persian newspaper articles. The reason for investigating the articles of newspaper is that most of the previous studies concerned with metadiscourse in educational fields like ESL and EFL teaching, and media, though being important, has not received much attention.

\section{The objectives of the present study}

As a matter of fact, this study aims in examining the following questions:

A) Is there any difference and similarities between interactional metadiscourse markers in English and Persian news articles?

B) What do these differences try to imply?

In the following, section 2 will present the concept of metadiscourse and will briefly review its theoretical and empirical backgrounds. Section 3 provides relevant information about the material, data collection and analysis procedures. Section 4 includes finding which consider the number and frequency of metadiscourse markers, followed by a discussion of results in section 5. Finally, section 6 will present conclusions, implication and limitations of the study and some suggestion for further research. 


\section{LITERATURE REVIEW}

"metadiscourse" also known as "meta language", "meta talk" and "meta communication", introduced by Zellig Harris in 1959. He employed this concept to describe ways of communication by language usage. So far, many researchers proposed various definitions and categorizations for this term. Meyer (1975) used the term "signaling" to talk about the non-content aspect of writing which emphasize some information in the text. In 1980, Schiffrin used "meta talk" to regard the textual features that contribute in demonstrating informational and referential aspect of writing and indicates the writer's stance toward text, as well. A year after, Williams indicated to "wordiness" as a key element which help the reader through the text. In the following years, Kopple (1985) and Crismore (1993) tried to reform the weakness and flaws of previous categorizations by proposing a better classification. Recently, Hyland suggested a new framework for metadiscourse markers which is derived from Thompson and Thetela model (1995). Before then, researchers speculated 2 levels of discourse. In the first level was the propositional aspect and the second level includes metadiscourse as non-propositional concept. Rejecting this assumption, Hyland claimed that these 2 levels depend on each other for creating a cohesive and coherent text; due to the fact that one level described external world, while the other regards the meaning in its relevant context. Together, they form reader's perception and interpretation of the text. Dividing metadiscourse markers into 2 levels-interactive and interactional- Hyland attempted to work out the ambiguity and overlap of previous studies.

The concept of metadiscourse has generated a lot of research in recent years. These studies could be classified into 3 fields:

A) Educational subjects like academic writing and reading comprehension

Table 1 represents the summary of some of the previous researches carried out in this sub-field.

TABLE1.

METADISCOURSE USE IN EDUCATIONAL SUBJECTS

\begin{tabular}{|c|c|c|c|c|}
\hline $\begin{array}{l}\text { Authors' } \\
\text { name }\end{array}$ & year & Subjects/texts & purposes & results \\
\hline $\begin{array}{l}\text { Intaraprawat } \\
\& \\
\text { Steffensen }\end{array}$ & 1995 & ESL university students persuasive writing & $\begin{array}{l}\text { To explore the usage of } \\
\text { metadiscourse markers in } \\
\text { writing }\end{array}$ & $\begin{array}{l}\text { Improvement of writing quality } \\
\text { due to the usage of metadiscourse } \\
\text { markers }\end{array}$ \\
\hline Camiciottoli & 2003 & $\begin{array}{l}\text { Using } 2 \text { economical texts with the same } \\
\text { content for } 55 \text { Italian university students }\end{array}$ & $\begin{array}{l}\text { To discover the influence of } \\
\text { metadiscourse markers on } \\
\text { reading comprehension }\end{array}$ & $\begin{array}{l}\text { Simpler and better understanding } \\
\text { of reading comprehension because } \\
\text { of metadiscourse markers }\end{array}$ \\
\hline Hyland \& Tse & 2004 & $\begin{array}{l}\text { University students' master thesis of } \\
\text { applied linguistics, Commercial studies, } \\
\text { computer science, electronic engineering, } \\
\text { biology and public administration }\end{array}$ & $\begin{array}{l}\text { To search the usage of } \\
\text { metadiscourse markers in } \\
\text { academic writing }\end{array}$ & $\begin{array}{l}\text { 1-Interactional metadiscourse as } \\
\text { the most frequent markers(esp. } \\
\text { hedges, transitions, and } \\
\text { engagement markers) } \\
\text { 2-The most usage of } \\
\text { metadiscourse in applied } \\
\text { linguistics } \\
\text { 3- The least usage of } \\
\text { metadiscourse in electronic } \\
\text { engineering }\end{array}$ \\
\hline $\begin{array}{l}\text { Jallilifar } \\
\& \\
\text { Alihosseini }\end{array}$ & 2007 & $\begin{array}{l}\text { Using } 3 \text { texts with the same content for } 3 \\
\text { groups of students with similar language } \\
\text { proficiency level }\end{array}$ & $\begin{array}{l}\text { To examine the effect of } \\
\text { metadiscourse markers on } \\
\text { reading comprehension }\end{array}$ & $\begin{array}{l}\text { Positive effect of metadiscourse } \\
\text { markers on reading } \\
\text { comprehension development }\end{array}$ \\
\hline $\begin{array}{l}\text { VahidDastjerdi } \\
\& \\
\text { Shirzad }\end{array}$ & 2010 & $\begin{array}{l}\text { University EFL students writing: } 30 \text { in the } \\
\text { elementary level, } 32 \text { in intermediate level } \\
\text { and } 30 \text { in advance level }\end{array}$ & $\begin{array}{l}\text { To investigate the employment } \\
\text { of explicit instruction in using } \\
\text { metadiscourse markers in EFL } \\
\text { writing }\end{array}$ & $\begin{array}{l}\text { 1-Direct impact of applying } \\
\text { instruction in using metadiscourse } \\
\text { on students' writing } \\
\text { 2-The most enhancement in } \\
\text { writing of intermediate students }\end{array}$ \\
\hline
\end{tabular}

B) Different genres

Table 2 illustrates the summary of carried out research in this sub-field. 
TABLE2

METADISCOURSE USE IN DIFFERENT GENRES

\begin{tabular}{|c|c|c|c|c|}
\hline $\begin{array}{l}\text { Authors' } \\
\text { name }\end{array}$ & year & Subjects/texts & purposes & results \\
\hline $\begin{array}{l}\text { Dafouz } \\
\text { milne }\end{array}$ & 2003 & $\begin{array}{l}\text { Opinion columns of two } \\
\text { elite newspapers in Britain } \\
\text { and Spain }\end{array}$ & $\begin{array}{l}\text { To investigate the pragmatic use of textual and } \\
\text { interpersonal metadiscourse markers in order to } \\
\text { achieve persuasion in newspaper discourse }\end{array}$ & $\begin{array}{l}\text { 1-The existing difference due to } \\
\text { the usage of hedge employment } \\
\text { 2-The frequent usage of textual } \\
\text { metadiscourse in Spanish news } \\
\text { articles } \\
\text { 3-The frequent usage of } \\
\text { interpersonal metadiscourse in } \\
\text { British news articles }\end{array}$ \\
\hline Gonzalez & 2005 & Commercial websites & To illuminate the role of textual metadiscourse & $\begin{array}{l}\text { The positive effect of } \\
\text { metadiscourse in persuading } \\
\text { customer }\end{array}$ \\
\hline $\begin{array}{l}\text { Zarei } \\
\& \\
\text { Mansouri }\end{array}$ & 2011 & $\begin{array}{l}\text { Randomly selected research } \\
\text { articles from } 2004 \text { to } 2006\end{array}$ & $\begin{array}{l}\text { To examine the role of metadiscourse markers in } \\
\text { humanities and non-humanities fields }\end{array}$ & $\begin{array}{l}\text { 1-The frequent usage of } \\
\text { interactive metadiscourse } \\
\text { markers in humanity fields } \\
\text { 1-The influence of metadiscourse } \\
\text { markers on text by engaging } \\
\text { readers }\end{array}$ \\
\hline $\begin{array}{l}\text { Hashemi } \\
\& \\
\text { Golparvar }\end{array}$ & 2012 & $\begin{array}{l}38 \text { randomly selected } \\
\text { Persian news articles in } \\
2012\end{array}$ & $\begin{array}{l}\text { To search the role of textual and interpersonal } \\
\text { metadiscourse in Iranian newspaper discourse }\end{array}$ & $\begin{array}{l}\text { 1-Textual metadiscourse as the } \\
\text { most frequent markers } \\
\text { 2-Higer usage of text } \\
\text { connectives, narratives and } \\
\text { commentaries }\end{array}$ \\
\hline
\end{tabular}

C) Comparative cross-cultural studies

Table 3 shows some research conducted in this sub-field.

TABLE3.

METADISCOURSE USE IN COMPARATIVE CROSS-CULTURAL STUDIES

\begin{tabular}{|c|c|c|c|c|}
\hline $\begin{array}{l}\text { Authors' } \\
\text { name }\end{array}$ & year & Subjects/texts & purposes & results \\
\hline Rahimpour & 2006 & $\begin{array}{l}90 \text { discussion section in } \\
\text { English and Persian research } \\
\text { articles in linguistics filed }\end{array}$ & $\begin{array}{l}\text { To investigate the impact of textual and } \\
\text { interpersonal metadiscourse markers on } \\
\text { writing }\end{array}$ & $\begin{array}{l}\text { Higher usage of textual } \\
\text { metadiscourse markers in Persian } \\
\text { research articles (esp. hedges and } \\
\text { transitions) }\end{array}$ \\
\hline Abdollahzade & 2007 & $\begin{array}{l}53 \text { English and Persian } \\
\text { newspaper } \\
\text { Editorials in } 2003\end{array}$ & $\begin{array}{l}\text { To examine the role of metadiscourse markers } \\
\text { in realizing writer's presence }\end{array}$ & $\begin{array}{l}\text { 1-Higher application of hedges } \\
\text { and code glosses in English } \\
\text { newspapers } \\
\text { 2- Higher application of } \\
\text { emphatics in Persian newspapers }\end{array}$ \\
\hline Burneikeite & 2008 & $\begin{array}{l}20 \text { English as L1 and } 20 \\
\text { Lithuanian as L2 master } \\
\text { thesis in Linguistics }\end{array}$ & $\begin{array}{l}\text { To expand the methodological framework in } \\
\text { analyzing metadiscourse and to investigate } \\
\text { the metadiscourse marker employment in } \\
\text { linguistics fields }\end{array}$ & $\begin{array}{l}\text { 1-The most frequent usage of text } \\
\text { connective in L2 } \\
\text { 2-The least frequent employment } \\
\text { of endophoric markers in L2 }\end{array}$ \\
\hline
\end{tabular}

The newspaper serves as an influential medium in keeping people informed world events and, thereby, in extending their knowledge and deepening their understanding. Despite the fact that newspaper still remain a powerful source of news; only few writers investigated the issue (Dafouz ,2003; Hashemi \& Golparvar ,2012).

Dafouz (2003) examined the role of metadiscourse markers in persuading readers. He investigated 40 opinion columns of 2 leading newspapers: the British "The Times" and the Spanish "EL Pais". The aim of his study was to determine the types of metadiscourse which occur in newspaper discourse and what is their distribution due to their cultural and linguistic differences. The findings indicated that hedge was the most frequent metadiscourse. The result of this study showed that balanced usage of both textual and interpersonal metadiscourse will be vital in persuasive text.

Hashemi \& Golparvar (2012) aimed at exploring the textual and interpersonal metadiscourse in Persian news articles. The corpus of their study included 38 news articles which were selected randomly. They utilized Kopple's classification to detect the frequency and types of metadiscourse. The findings marked text connective, narratives and commentary respectively as the most useful metadiscourse markers in newspaper discourse.

Generally speaking, newspaper as an important genre has not received much attention outside of European and US. (Crismore \& Abdollahzade, 2010). Therefore, this study tries to present a comparative analysis interactional metadiscourse in news articles written by American and Iranian journalists.

\section{Methodology}

\section{A. Material}

The data of the present study were collected from leading and most widely read newspapers in US. and Iran by means of random sampling. The English news articles were retrieved from an online newspaper archive, while Persian 
were collected from Astan-e-Qods- Razavi library archive. The selected articles were matched for length and topic to ensure comparability. They were written by American (as native-English speaking writers) and Iranian (as nativePersian speaking writers). These writers all tried to cover 9/11 events in 2001 .

TABLE4

SIZE OF CORPUS

\begin{tabular}{|l|l|l|}
\hline Size of corpus & English & Persian \\
\hline Number of articles & 30 & 30 \\
\hline Number of words & 1,815 & 1,780 \\
\hline
\end{tabular}

The news does not consist of only facts about events and issues of the world; rather, news, in addition to the fact, is full of opinion, value judgment, bias, and distortion of reality. So far, 9/11 was one of the argumentative events which could not be covered neutrally by the journalist; hence, metadiscourse enables readers to find out the way journalists used to manipulate the news.

\section{B. Data Collection Procedure}

To investigate the role of metadiscourse markers, 30 English and Persian news articles (15 from each newspaper) were collected randomly. In fact, Random sampling is a contributing factor to overcome the diversity of writers' styles. All of these articles were published on 12 September in 2001. The reason why 9/11 news was chosen in this analysis is the importance of the event and its reflection and impacts on the world.

\section{Data Analysis}

In analyzing the data, Hyland (2005) classification of metadiscourse was utilized. (See table 5). This model has been chosen due to the fact that its categorization is more elaborated and frequently used in current studies. (For further study refers to Ken Hyland (2005) in "metadiscourse: exploring interaction I writing" (p.49)).

TABLE5.

HYLAND'S (2005) CLASSIFICATION OF INTERACTIONAL METADISCOURSE

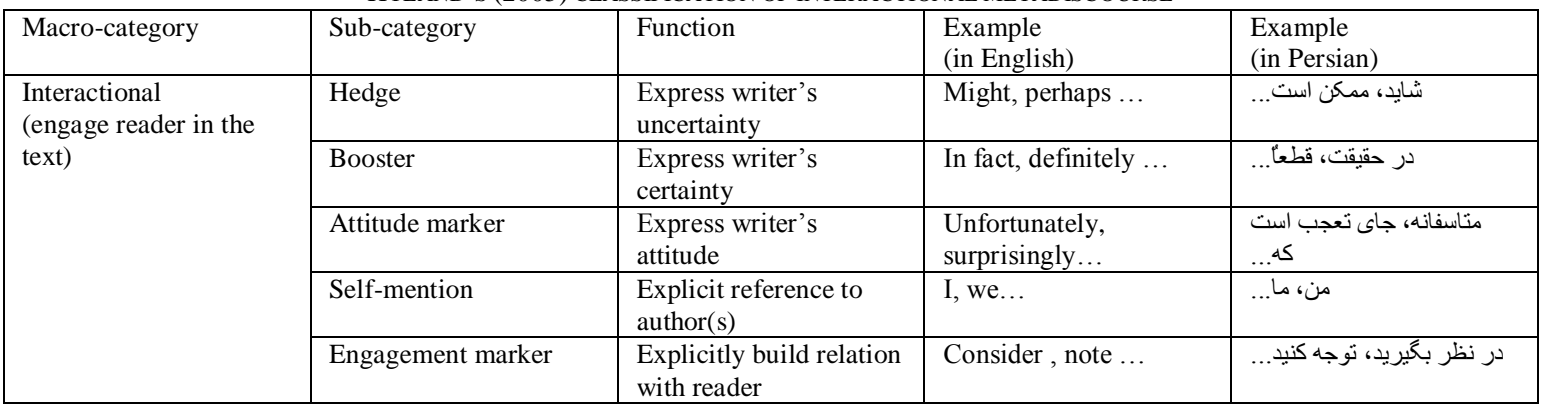

In the following, some examples of interactional metadiscourse in English and Persian are underlined parts of the sentences:

1- $\underline{\text { About }} 50000$ people work at the trade center.

2- In the wake of Pearl Harbor, we knew our enemies.

3- In American history, only one comparable event springs obviously to mind: Pearl Harbor

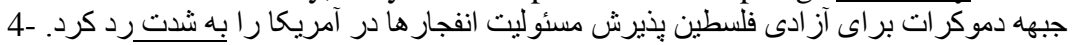

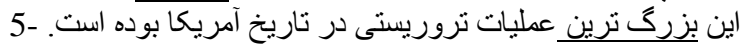

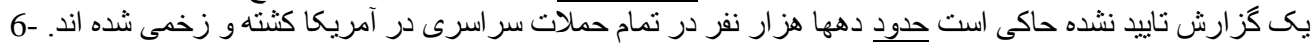

All news articles were examined to determine and classify metadiscourse markers manually, and a quantitative analysis was conducted in order to identify the frequency of different types of metadiscourse and to answer the research questions. To normalize the present study to a common basis to compare the frequency of occurrence, this research employed 200 words approach.

Furthermore, to analyze the data statistically, SPSS software was applied.

To find out whether there is any difference between the metadiscourse distribution in both English and Persian news and to explore the meaning beyond this difference, the Chi-square test was employed.

\section{RESULTS}


TABLE6

METADISCOURSE NUMBERS AND FREQUENCIES IN CORPUS

\begin{tabular}{|l|l|l|l|l|}
\hline \multirow{2}{*}{$\begin{array}{l}\text { Interactional metadiscourse } \\
\text { markers }\end{array}$} & \multicolumn{2}{l}{$\begin{array}{l}\text { Frequency of metadiscourse } \\
\text { markers }\end{array}$} & \multicolumn{2}{l|}{$\begin{array}{l}\text { percentage of metadiscourse } \\
\text { markers }\end{array}$} \\
\cline { 2 - 5 } & English & Persian & English & Persian \\
\hline Hedge & 58 & 21 & $38 \%$ & $32 \%$ \\
\hline Booster & 28 & 13 & $18 \%$ & $20 \%$ \\
\hline Attitude markers & 40 & 31 & $26 \%$ & $48 \%$ \\
\hline Self-mention & 18 & 0 & $12 \%$ & 0 \\
\hline Engagement markers & 9 & 0 & $6 \%$ & 0 \\
\hline
\end{tabular}

As it can be seen in table 6, the number of interactional metadiscourse markers employed by American journalists (70 \%) is higher in comparison with Iranian journalists $(29 \%)$.

In the news articles written by American journalists, hedges were the highest metadiscourse marker (38\%), followed by attitude markers $(26 \%)$, booster (18\%), self-mention (12\%), and engagement marker (6\%).

In Persian news articles, attitude markers were the most frequent interactional metadiscourse marker (48\%), followed by hedge $(32 \%)$, and booster $(20 \%)$. Table 3 clearly shows that Iranian journalists did not employ self-mention and engagement marker.

Detecting the difference between English and Persian interactional metadiscourse, the chi- square test was applied.

In English news articles, the chi-square test disclosed the following results:

a) Between hedges and boosters, the asymptotic significance $(0.001)$ is less than 0.05 which indicates the significant difference between these two markers; where hedges are employed more frequently.

b) Between hedges and self-mention, the asymptotic significance (0.000) is less than 0.05 and it shows the difference between these metadiscourse markers is significant; as hedges are used more than self-mention.

c) Between hedges and engagement markers, the asymptotic significance $(0.000)$ has been less than 0.05 that reveals the difference; since the usage of hedges are higher.

d) Between boosters and engagement markers, the asymptotic significance (0.002) is less than 0.05. This displays the fact that these two markers differ significantly. In fact, boosters are used more frequently.

e) Between attitude markers and self-mention, the asymptotic significance (0.004) is less than 0.05 , and the clear difference points out the application of attitude markers are higher.

f) Between attitude markers and engagement markers, the asymptotic significance (0.000) is less than 0.05 . Furthermore, the existing difference is significant; for the fact that attitude markers are used more.

Nevertheless, there is no significant difference between hedges and attitude markers $(\mathrm{p}=0.069>0.05)$, boosters and attitude markers $(\mathrm{p}=0.146>0.05)$, boosters and self-mentions $(\mathrm{p}=0.140>0.05)$, and self-mention and engagement markers $(\mathrm{p}=0.083>0.05)$.

In Persian news articles, the chi-square result demonstrated no significant difference between hedges and boosters $(\mathrm{p}=0.170>0.05)$, and hedges and attitude markers $(\mathrm{p}=0.166>0.05)$. However, the difference between boosters and attitude markers was significant $(\mathrm{p}=0.007>0.05)$, due to the fact that application of attitude markers were higher.

Comparing English and Persian articles chi-square results revealed that the usage of boosters $(p=0.019>0.05)$ and $(\mathrm{p}=0.258>0.05)$ include no significant difference, while hedge employment showed significant difference $(\mathrm{p}=0.069>$ 0.05), for as much as hedges are the most numerous metadiscourse markers in English news articles.

\section{Discussion}

Hyland (2005) believes that interactional resources help writers making their inputs clear and engaging their readers in the text. Hence, these types of metadiscourse express solidarity and point toward the relation writer tries to build with his/ her reader and text.

Similarities have been found in the corpus indicate that three interactional metadiscourse markers- hedges, boosters and attitude markers- are used more in English and Persian news articles; yet the statistical differences among these three markers are significant.

English and Persian news articles differ in the way they prioritize metadiscourse sub-categorizations. Therefore, the analysis of these presented data illustrates that in English news articles, the amount of interactional metadiscourse markers exerted by American journalist are higher. It is due to the fact that they are concerned with reader-writer responsibility. In spite of the fact that Iranian journalists prefer to act conservatively especially about political (such as 9/11) and religious matters, they inclined toward writer responsibility.

The findings also revealed that American journalists employed self-mention and engagement markers in their articles. The reason why there is no sign of these two metadiscourse markers in Persian news articles is because of their different writing styles in formal contexts. Iranian writers have trained to use a third person pronoun and passive structure in order to avoid self-mentioning in their text, while English writers feel free to a part of the text they are writing. The other motive is due to Iranian journalism conservatism and their writer responsibility approach toward text.

In comparison with Iranian (32\%), American journalists applied hedges (38\%) as the most frequent metadiscourse marker, while there was no significant difference in using boosters and attitude markers in their articles. Hyland (2005) claimed that American writers tend to be cautious and tentative. By exerting hedge, it seems that journalists are trying 
not to show that they are knowledgeable about the proposition. Therefore, they express their uncertainty or their lack of commitment toward the truth conditions, particularly since $9 / 11$ is a political subject and yet argumentative one. Intraprawat and steffenson's (1995) study pointed out that writers would achieve success by using hedge more frequently. Thus, it might be a good idea for Iranian journalists to go through training courses for expanding the usage of this type of metadiscourse marker.

The analysis of the data also revealed that there is no significant difference in employing boosters in English (18\%) and Persian (20\%). This indicates that Iranian and American journalists did not intend to represent a high degree of certainty and preferred to conduct their readers by leaving the alternative viewpoints open.

According to Hyland (2005), attitude markers refer to "writer's affective, rather the epistemic, attitude to proposition, as they convey concepts like surprise, anger, agreement and so on" (p.53). Comparing the application of attitude markers in corpus, it can be seen that Persian news articles involve a higher degree of this metadiscourse marker (48\%) than the Americans (26\%). Attitude markers are contributing factors in helping readers realize not only the necessary propositional contents, but also the writer's stance toward the subject. Iranian journalist tried to demonstrate their news articles devoid of being dull and impersonal by using this aspect of metadiscourse more frequently. They also tend to show their stance implicitly instead of free using of self-mention.

\section{CONCLUSION}

This study tried to investigate the role of interactional metadiscourse markers about 9/11 news articles published in 2001 in US. and Iran. It also intended to illustrate the frequency of metadiscourse markers and to explore the difference between these two types of news articles. The result of the present study disclosed that interactional metadiscourse are more utilized by American journalists.

The findings also indicate that, among the interactional metadiscourse, the employment of hedge, booster and attitude marker are higher. In addition, hedges had the highest usage in English news articles, whereas attitude markers topped in Persian articles. However, there was no significant difference in booster application in the corpus. This is perceived from the results that besides linguistic difference between Iranian and American journalists, there are culturally different, as well. It can be exemplified through their writing styles in formal contexts and their responsibility toward the relations they are trying to build with readers, text.

This comparative study might provide pedagogical implication. It would be practical to train journalism students about using metadiscourse markers appropriately in order to achieve more success in reporting the world's events. Hence, journalists by exerting metadiscourse markers not only would be able to deepen their readers' understanding, but also might ensure to conduct them to grasp the content completely and ideally.

\section{APPENDIX A}

All of the English news articles used in this study were retrieved from:

http://www.newseum.org/todaysfrontpages/archive.asp

http://www.latimes.com/news/nationworld/nation/september11/la-11pages, 0,862645.htmlstory\#axzz2kQA197Ot

http://voices.washingtonpost.com/blog-post/2010/09/911_on_newspapers_front_pages.html

It should bear in mind that since Iran is under strict sanction, the above internet websites were the only resources.

All of the Persian news reports were collected from Astan-e-Qods-e-Razavi library which is located in Imam Reza Holy Shrine in Mashhad, Iran.

\section{REFERENCES}

[1] Abdollahzade, E. (2007). Writer's presence in Persian and English newspaper editorial. Paper presented at the International Conference on Systemic Functional Linguistics in Odense, Denmark.

[2] Burneikaité, N. (2008). Metadiscourse in Linguistics master's theses in English L1and L2. Kallbotyra,59(3),38-47.

[3] Camiciottoli, B.C. (2003). Metadiscourse and ESP comprehension: an exploratory study. Reading in a Foreign Language, $15(1), 15-44$.

[4] Crismore, A. et al. (1993). Metadiscourse in persuasive writing: a study of text written by American and Finnish university students. Written Communication,10(1),39-71.

[5] Crystal, D. (1987). The Cambridge Encyclopedia of Language. Cambridge: Cambridge University Press.

[6] Dafouz, E. (2003). Metadiscourse revisited: a contrastive study of persuasive writing in professional discourse. Estudios Ingleses de la Universidad Complutense,11,29-57.

[7] Finch, G. (2000). Linguistics Terms and Concepts. Palgrave Macmillan

[8] González, R. A. (2005). Textual metadiscourse in commercial websites. IBÉRICA 9, 33-52.

[9] Hashemi, M.R. and Golparvar, E. (2012). Exploring metadiscourse markers in Persian news reports. International Journal of Social Science Tomorrow, 1(2),1-6.

[10] Hyland, K. (2005). Metadiscourse: Exploring Interaction in Writing. London: Continuum Discourse Series.

[11] Hyland, K. and Tse, P. (2004).Metadiscourse in Academic Writing: A Reappraisal. Applied linguistics,25(2), 156-177.

[12] Intaraprawat, P. and Stsffensen, M.(1995). The use of metadiscourse in good and poor ESL essays. Journal of Second Language Writing, 4(3) ,253-272. 
[13] Jalilifar, A. and Alipour, M. (2007). How explicit instruction makes a difference: Metadiscourse markers and EFL learners' reading comprehension skill. Journal of College Reading and Writing,38(1), 35-52.

[14] Meyer, B.J.F. (1975). The Organization of Prose and its Effects on Memory. Amesterdam: North-Holland.

[15] Rahimpour,S. (2006). Contrastive rhetoric of English and Persian texts: Metadiscourse in Applied Linguistics Research Articles. Unpublished master's thesis. University of Mashhad.

[16] Schiffrin, D. (1980). Meta talk: organizational and evaluation brackets in discourse. Sociological Inquiry Language and Social Interaction,50(3-4), 199-236.

[17] Thompson, G., and Thetela, P. (1995). The sound of one hand clapping: the management of interaction in written discourse. TEXT,15(1), 103-127.

[18] VahidDastjerdi, H., and Shirzad, M. (2010). The impact of explicit instruction of metadiscourse markers on EFL learners' writing performance. Journal of Teaching Language Skills(JTCS),2(2), 155-174

[19] Vande Kopple, W.(1985). Some exploratory discourse on metadiscourse. College Composition and Communication, 36, 82-93.

[20] Williams, S. (1981). Styles: Ten Lessons In Clarity and Grace. Boston: Scott Foresman and Co.

[21] Zarei, G.R. and Mansouri, S. (2007). Metadiscourse in academic prose: a contrastive analysis of English and Persian research articles. The Asian ESP Journal, 3(2), 24-40.

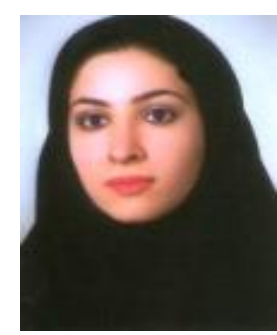

Sara Yazdani was born in 1984 and is a M.A. Student in linguistics at the English department of Ferdowsi University, Mashhad, Iran. She received her B.A. in English translation from Imam Reza University, Mashhad. Her research interests lie in critical discourse analysis and pragmatics.

Shahla Sharifi is an associate professor in Ferdowsi University of Mashhad, Iran. Her research interests are pragmatics, discourse analysis and neurolinguistics.

Mahmmud Elyasi is an assistant professor in Ferdowsi University of Mashhad, Iran. He is interested in pragmatic and sociology. 